\title{
Monke Joins Committee to Revise Standards
}

Arthur Monke, librarian at Bowdoin College in Brunswick, Maine, has been appointed to the ACRL Committee to Revise the 1959 Standards for College Libraries. Mr. Monke replaces Barbara G. LaMont, who has recently resigned from the committee for personal reasons.

The committee, chaired by Johnnie Givens, librarian at Austin Peay State University in Tennessee, has prepared a set of background/ working papers which are available from the Executive Secretary, ACRL, 50 E. Huron St., Chicago, IL 60611. Miss Givens has discussed the progress of the committee at a recent meeting of the Pennsylvania Library Association and at the Midwest Academic Librarians Conference in Milwaukee.

At the ALA New York Conference in July, the committee will hold a series of hearings. Interested persons are invited to present their comments on the revision of the standards at any time during the following scheduled hours: Wednesday, July 10, from 2:00 to 6:00 p.m., and Thursday, July 11, from 9:00 a.m. to 12:00 noon.

The committee acknowledges its appreciation for the support of a J. Morris Jones-World Book Encyclopedia-ALA Goals Award, which has funded the first year of the project.

\section{Inside Washington}

\author{
Christopher Wright \\ Assistant Director \\ ALA Washington Office
}

Like some wayward streetcar, copyright law revision continues to grind along, passengers grumbling, stops bypassed, schedule lost, destination forgotten. Exhausted riders still shout directions: "that way to Fair Use," "turn at Manufacturing Clause," "when do we get to Cable Television?" Among themselves, some have resorted to epithets, calling each other "record pirates" or "systematic copiers."

Observing the faltering progress of this tenyear odyssey, passenger Barbara Ringer, the Register of Copyrights, announced last month that "at some point you have to say this streetcar's at the end of the line and it's time to get another one." The copyright revision omnibus, S.1361, was breaking down. There was now "no chance" it would reach its destination this Congress. "In my opinion, it's had it."

Instead, Ringer urged fellow passengers to abandon their seats and resort to other means of transport taking them to their own separate destinations. Russian authors this way, expiring copyrights there, sound recordings that way, photocopying there.

Ringer's announcement came only days after the latest version of the copyright bill, a committee print of Senator John McClellan's Subcommittee on Patents, Trademarks and Copyrights, was made public. Early in April, the subcommittee's chief counsel, Thomas C. Brennan, told librarians and publishers over lunch that he too saw "absolutely no chance" of the bill's passage during this Congress.

As a result, said Brennan, there would be interim legislation aimed at specific immediate problems, including library photocopying. Something must be done to get the various parties back speaking together and on the road to a solution.

Brennan suggested that Congress might enact Title II of the bill, which establishes a national commission on new technological uses of copyrighted works, and give the commission eighteen months to come up with a solution to the photocopying problems.

Ringer told the meeting of federal librarians that she expected Congress and the publishing interests to press for establishing the commission as part of the copyright office itself. Asked if she was requesting funds for such a project, she said, "No, but I think others will."

Although the principal stumbling block in revising copyright continues to be the endless dispute over cable television, the issue of photocopying is rapidly becoming, in Ringer's words, "the most dangerous, most difficult, and most urgent problem. . . ." Photocopying would be the commission's first order of business. 
Meanwhile, the rhetoric has been growing stronger.

A New York Times article on Sunday, March 24 , described the newly formed Research Libraries Group (RLG)-Columbia, Yale, Harvard, and N.Y. Public-as "a sweeping and controversial program of combined operations that will entail cutting back purchases of many publications and systematically exchanging photocopies of previously published writings."

The implication was that now, with Williams \& Wilkins in the libraries' favor, the four institutions were preparing to set up a massive photocopying operation. The word "systematically" occurred repeatedly in the article, which was followed shortly by a blast from Townsend Hoopes, president of the Association of American Publishers. Hoopes accused the group in an April 12 Times article of "the deliberate intention of avoiding the payment of royalties and even for avowedly systematic and unlimited photocopying."

Presumably on the strength of the Times article, Brennan told the April 4 luncheon meeting that the new bill would definitely prohibit the kind of photocopying planned by the New York group, although it would allow "isolated" copying in the course of normal interlibrary loans, as before.

Yet there is no mention of "systematic photocopying" in the RLG prospectus, which dwells almost entirely on administrative measures and collection development. Warren J. Haas, Columbia University librarian and a spokesman for the group, called the photocopying accusation "a red herring." Said Haas, "The plans of the Research Libraries Group have meticulously observed the principle of a single copy for a single patron. We're talking about sending books back and forth on buses, about delivering materials, not copying materials."

But the image remains. To the publishers, the new breed of library network means sharply reduced sales thanks to "systematic photocopying" and cooperative collection.

The publishers argue that all photocopying of rare scientific journals should be subject to licensing and royalties. But librarians fear that any concession on licensing will destroy the concept of fair use for individual library patrons. The problem, in addition, is to define

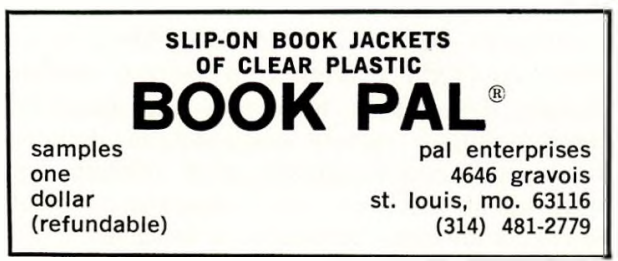

"systematic." To a librarian it means one thing, to a publisher it means something else. Williams \& Wilkins didn't help. One judge decided that was systematic, the other decided it wasn't.

The revised copyright bill is no help either. Library photocopying rights "extend to the isolated and unrelated reproduction or distribution of a single copy or phonorecord of the same material on separate occasions, but do not extend to cases where the library or archives, or its employee ... engages in the systematic reproduction or distribution of single or multiple copies or phonorecords of material described. ..."

Nor does the committee report, still in confidential draft form, shed any light on the matter. "While it is not possible to formulate specific definitions of "systematic copying'," the report concedes, "the following examples serve to illustrate some of the copying prohibited." Two of the three examples are vaguely like the National Library of Medicine and the National Institutes of Health, the parties of the successful Williams \& Wilkins defense. But you can't be sure.

Because of this built-in uncertainty, the draft legislation fails to answer the judges in the Williams \& Wilkins case, when they concluded "the truth is that this is now preeminently a problem for Congress. ..." Because so far Congress has not conclusively answered the judges' question as to what is fair and unfair in photocopying.

Meanwhile libraries and publishers continue to jostle for position. At the Center for Research Libraries in Chicago, a micropublisher has proposed charging the center seven times its normal price because it says it loses seven sales every time the center acquires one of its publications. And the issue of blanket licensing, giving libraries license to copy as often as they want after paying a premium price for a publication, is gaining acceptance in some quarters.

In spite of the assurances of those closest to the legislation, there is always the diabolic chance that the old omnibus bill will rattle through Congress at some late hour in its present inconclusive form. Or, if Congress establishes the copyright commission to study photocopying, there is the chance that the commission's decision will go against libraries, or still fail to answer the basic question. Much will depend on the makeup of the commission and whose interests get their day in court. The first step toward a solution to photocopying may lie in the choice of commission members. This decision is up to Congress.

Meanwhile, librarians continue to maintain regular contact with members of the publishing community through ALA's copyright committee, and the search for a workable compromise goes on. 